\title{
W STRONĘ MIASTOTWÓRCZEGO BEZRUCHU?
}

Każda rzecz, o ile jest sama w sobie, usiłuje pozostawać $w$ swoim istnieniu

Benedykt Spinoza

\section{UWAGI WSTĘPNE}

Jedną z najbardziej mylących, dezorientujących i zarazem maskujących prawdziwy obraz życia społecznego kategorii socjologicznych była i jest kategoria działania. Owo działanie, zarówno w ujęciu Weberowskim i postweberowskim, w ujęciu interakcjonistów symbolicznych (poczynając od George'a Herberta Meada, poprzez Herberta Blumera, a na Ervingu Goffmanie kończąc), jak i np. w ujęciu Guya Deborda i sytuacjonistów, jawi się w socjologii jako najważniejszy, czasem wręcz jedyny czynnik sprawczy przesądzający o obliczu porządku społecznego, o jego stabilności bądź płynności.

Niezależnie od tego, czy działanie jest rozumiane jako rezultat myślenia celowo-racjonalnego, czy traktuje się je jako coś nawykowego, jako wypadkową pojedynku toczącego się między rozumem i sercem, jako produkt emocji czy też jako efekt psychobiologicznego zaprogramowania, którego mechanizm jest w stanie rozpoznać dopiero neuronauka, zawsze właściwie ten, k to d zi ała, prezentuje się (jest prezentowany) w socjologii jako podmiot i twórca. Czasami również i niejako przy okazji - jako agresor, ciemiężyciel, sprawca społecznych nierówności oraz bezwzględny egzekutor zasad ładu, będących tak naprawdę zasadami ustalającymi relacje władzy.

Być może jednak, porządek zbiorowy trwa i reprodukuje się (a nawet rozwija) nie tyle dzięki działaniom społecznym, ile dzięki zaniechaniom. Innymi słowy, warto przez chwilę spróbować sobie wyobrazić świat społeczny, który jest konstruowany, umacniany, potwierdzany, legitymizowany i reprodukowany nie dzięki akcjom, nie dzięki performance'om, ale dzięki rezygnowaniu z zamiarów, dzięki przemilczaniu, dzięki schodzeniu sobie z drogi, dzięki powstrzymywaniu się i wycofywaniu.

Warto, moim zdaniem, podjąć tę próbę przynajmniej z dwóch powodów. Po pierwsze, rezygnowanie z zamiarów, przemilczanie, schodzenie sobie z drogi, powstrzymywanie się i wycofywanie to niepomiernie częstsze sposoby wpisywania się w codzienność niż ich odwrotności. Po drugie, często, znacznie częściej, niż to się może zdawać na pierwszy rzut oka, najważniejszym celem 
aktywności podejmowanych przez jednostki, grupy, organizacje i instytucje jest powstrzymanie czyichś działań. Wbrew temu, co zakłada i co przyjmuje za oczywistość cztery piąte współczesnych teorii socjologicznych, bardzo dużo, może nawet większość zaprojektowanych, przekalkulowanych i podjętych akcji wcale nie ma prowadzić do takich bądź innych reakcji, ale ma unieruchamiać. Interakcyjność (i interaktywność), dialogowość oraz dyskursywność to świetnie brzmiące słowa klucze, za pomocą których chętnie opisujemy jako socjologowie zarówno domniemywaną przez nas naturę porządku społecznego, jak i jego najbardziej pożądaną i oczekiwaną przez nas postać. Kłopot w tym, że wcale nie musimy mieć racji.

Chciałbym w tym krótkim artykule spróbować spojrzeć na polityki (i ideologie) miejskie przez pryzmat pytania, w jaki sposób podchodzą one do kwestii upodmiotowienia i uruchamiania społeczności miejskiej, jak odnoszą się one do idei partycypacji oraz jak zapatrują się na rozmaite formy miejskiego aktywizmu. Wbrew pozorom i na przekór pewnej wyraźnej modzie, bardziej niż wszelkie możliwe pożytki wynikające z obywatelskiej aktywności (które wydają się oczywiste) interesować mnie tu będa „pułapki obywatelskiego zaangażowania”.

\section{PRZYPADEK PIERWSZY: MIASTO WIECZNEJ PRÓBY GENERALNEJ}

Właściwie wszyscy urzędujący politycy miejscy są nieprzerwanie krytykowani za podejmowanie nieskutecznych lub pociagajacych za sobą złe skutki działań. Aż prosi się, aby zareagować na tę sytuację stara, zdroworozsądkową dyrektywą prakseologiczna, która radzi uciekać w nicnierobienie. Kłopot w tym, że nie jest do końca jasne, czy politykom miejskim rzeczywiście bardziej opłaca się leniuchowanie - gdyż finansowe, społeczne i polityczne koszty nicnierobienia sa ostatecznie mniejsze niż koszty nieakceptowanej przez stronę społeczną aktywności, czy też lepszą dla nich strategią jest (jednak) podejmowanie jakichś działań.

Najbezpieczniejszym dla rządzących rozwiązaniem okazują się w tej sytuacji rozmaite prace studialne, rozmaite przymiarki, szkice i programy pilotażowe. Dobrym pomysłem jest także inicjowanie i przeciaganie konsultacji społecznych. I w jednym, i w drugim wypadku chodzi o tworzenie czegoś w rodzaju poczekalni decyzyjnej; chodzi o stworzenie i rozbudowywanie przestrzeni, w której rządzi logika próby generalnej i w której wprawdzie decyduje się i działa, ale niejako wstępnie, rozpoznawczo, zwiadowczo - toruje się droge prawdziwie ważnym decyzjom i prawdziwie ważnym działaniom.

Wydaje się to dla wszystkich wygodne. Dla rządzących - ponieważ nie można im zarzucić, że zupełnie nic nie robią. Dla rządzonych - ponieważ owe działania-przymiarki pozwalająim zachować wiarę, że sprawujący władzę w końcu przystapią do działań właściwych. Trzecia ważna grupa beneficjantów „polityki permanentnej próby generalnej” to najrozmaitsi eksperci, analitycy, diagności, konsultanci itd., którzy wyspecjalizowali się w dostarczaniu rzą- 
dzącym (ale także np. mediom i organizacjom pozarządowym) materiałów mających ułatwić i przyspieszyć przejście od dyskusji do decyzji i od decyzji do działań. Wszyscy ci eksperci, analitycy, diagności i doradcy sa z jednej strony akuszerami działań politycznych (a często również ich współprojektantami i potencjalnymi współwykonawcami). Z drugiej jednak strony, paradoksalnie, wszyscy oni przyczyniają się również do odraczania działań, do unieruchomienia maszyn-instytucji majacych działać i - działając - rozwiązywać problemy. Co więcej, wydaje się (i to jest następny paradoks), że unieruchamiająca moc rozmaitych ekspertyz, analiz, diagnoz itd. jest dzisiaj tym większa, im bardziej sa one rzetelne. Innymi słowy: im uczciwiej informują one o różnorodnym ryzyku i zagrożeniach związanych z planowanymi działaniami, tym silniej do nich zniechęcaja.

Niestety jednak, ucieczka w planowanie też bywa niebezpieczna. Warto zwrócić uwagę, że większość podejmowanych przez mieszkańców miast akcji protestacyjnych (przyjmujacych, w swej najostrzejszej formie, postać blokad i okupacji, w najłagodniejszej zaś - petycji) nie odnosi się do „polityk w toku”, lecz do zamiarów rządzących ${ }^{1}$. Dzieje się tak choćby dlatego, że łatwiej uwierzyć w sukces polegający na niedopuszczeniu do urzeczywistnienia czegoś, czego jeszcze nie ma, niż w sukces, który miałby polegać na likwidacji bądź zreformowaniu czegoś, co choć nie funkcjonuje dobrze, to jednak już istnieje i zostało jakoś oswojone. Dzieje się tak również dlatego, że o budzących społeczne zastrzeżenia oraz niepokoje planach i projektach rządzących można powiedzieć praktycznie wszystko. Fakt, że w warunkach rosnącej złożoności wszystkich możliwych porządków (społecznego, technologicznego, kulturowego, organizacyjnego itd.) nie sposób do końca przewidzieć, jak zadziałaja sygnowane przez władzę projekty, sprawia, że każdy z nich da się uczynić przedmiotem dowolnej krytyki.

To, że na liście grzechów najczęściej wytykanych rządzącym miastami politykom znajdują się - od pewnego czasu - nie tylko działania, lecz także zamiary, musi prowadzić do szukania nowych, potencjalnie bezpieczniejszych sposobów funkcjonowania struktur władzy miejskiej. Nietrudno zgadnąć, że najlepszym zabezpieczeniem przed ponoszeniem kosztów niepopularnych decyzji, niepopularnych działań i niepopularnych projektów jest polityka zorientowana na dzielenie się odpowiedzialnością i wikłanie we współodpowiedzialność, słowem - polityka włączania jak największej liczby mieszkańców $\mathrm{w}$ procedury partycypacyjne ${ }^{2}$.

\footnotetext{
${ }^{1}$ Mowa tu zarówno o typowych niepopularnych inwestycjach typu oczyszczalnie ścieków, spalarnie śmieci czy komunalne krematoria, w wypadku których jest właściwie pewne, że samo ogłoszenie zamiaru ich budowy pociagnie za sobą społeczne protesty, jak i każdej właściwie sytuacji, kiedy rządzący, gdy mają możliwość wybierania między kilkoma równorzędnymi i niekoniecznie kontrowersyjnymi opcjami (inwestycyjnymi, organizacyjnymi), wybierając którąkolwiek z nich, ściagają na siebie pretensje zwolenników wszystkich pozostałych.

${ }^{2}$ Zob. M. Miessen, Koszmar partycypacji, Wydawnictwo Fundacji Bęc Zmiana, Warszawa 2013, na ten sam temat zob. również: K. Nawratek, Miasto jako idea polityczna, w: idem, Dziury w catym. Wstep do miejskich rewolucji, Wyd. Korporacja Ha!art, Kraków 2008 oraz R. Drozdowski, M. Frackowiak, Bilans społecznej wyobraźni. Komentarz socjologiczny do Poznańskiego Budżetu Obywatelskiego, „Ruch Prawniczy, Ekonomiczny i Socjologiczny” 75, 2013, z. 4.
} 


\section{PRZYPADEK DRUGI: RUCH(Y) W MIEŚCIE}

Odkąd zaczęło się rozpowszechniać pojmowanie społeczeństwa jako zbioru relacji oraz jako sieci ${ }^{3}$, zaczęto również zupełnie inaczej mówić o znaczeniu i funkcjach różnych rodzajów aktywności podejmowanych przez indywidualnych i zbiorowych aktorów społecznych. Dla Marka Krajewskiego synonimem i zarazem świadectwem posiadania realnej władzy jest dzisiaj sama zdolność prowokowania i kierunkowania ruchu w coraz bardziej złożonych sieciach społecznych ${ }^{4}$. Socjologowie (i ekonomiści) Internetu dawno już spostrzegli, że warunkiem finansowego sukcesu mnożących się jak grzyby po deszczu portali, serwisów i platform internetowych jest ich zdolność do „zarządzania uwaga”. Swoista fetyszyzacja ruchu (i umiejętności uruchamiania społeczeństwa) towarzyszy dziś również refleksji na temat demokracji i społeczeństwa obywatelskiego. Zewsząd słychać więc nawoływania do aktywizacji takich lub innych zmarginalizowanych bądź marginalizowanych zbiorowości i grup społecznych - nie dość jakoby aktywnych, wyczekujących i pogrążonych w apatii. W ciągu ostatnich kilku lat błyskotliwą karierę zrobiło pojęcie partycypacji. Mnożą się projekty i programy, których celem jest przekonanie nieuczestniczących (w kulturze, w życiu politycznym, w życiu społeczności lokalnej itd.) do uczestnictwa.

Od pewnego czasu najbardziej widocznymi rzecznikami aktywizowania, upartycypacyjniania i uruchamiania społeczeństwa (rzecznikami odwoływania się do zasobów jego wyobraźni, kreatywności, do jego planistyczno-designerskich intuicji, do jego potencjałów emancypacyjnych itd.) są aktywiści i sympatycy ruchów miejskich. Problem w tym, że zarządzanie miastem przez aktywizowanie i uwalnianie zablokowanych dotąd, z takich czy innych powodów, potencjałów społecznych okazać się może - co najmniej z dwóch powodów zadaniem znacznie trudniejszym, niż mogłoby się to zdawać na pierwszy rzut oka. Po pierwsze, nigdzie nie jest powiedziane, że autentyczna innowacyjność oraz konstruktywność odblokowywanych potencjałów społecznych są wystarczająco duże, by uruchomić procesy prowadzące do zmian na lepsze. Po drugie, nigdzie nie jest powiedziane, że aktywiści ruchów miejskich ufają (i będą ufać w przyszłości) wszystkim bez wyjątku oddolnym intuicjom społecznym dotyczącym tego, jak ma wyglądać i jak ma funkcjonować dobrze urządzone miasto. Prawdę mówiąc, byłoby dziwne, gdyby ufali. Znaczyłoby to, że ślepo akceptują pewną postać miejskiego populizmu opierającego się na wierze, iż dobre dla miasta rozwiązania to wyłącznie te rozwiązania, które (samo)organizują i przy okazji (samo)legitymizują się oddolnie.

Kluczowe wydaje się jednak coś jeszcze innego. Otóż nikt w zasadzie nie stawia dziś na serio pytania o to, jaki poziom obywatelskiego zaangażowania jest/byłby/powinien być (i dlaczego) poziomem optimum. Inaczej mówiąc, nie dopuszczamy do siebie myśli (uznając ją z góry za nie-

${ }^{3}$ Por. M. Castells, Społeczeństwo sieci, WN PWN, Warszawa 2007.

${ }^{4}$ Zob. M. Krajewski, Wtadza horyzontalna. O życiu po śmierci Michaela Jacksona, w: M. Staniszewski (red.), Miasto przywództwa. Pojęcia podstawowe, Wyd. Pass, Warszawa 2010. 
dorzeczna), że poziom zaangażowania obywatelskiego może być - w określonych okolicznościach, w określonych uwarunkowaniach, w określonym splocie indywidualnych i grupowych interesów - nie tylko z a niski, lecz także z a wysoki. Tym samym akceptujemy jednak rozumowanie, zgodnie z którym Comte'owskiej dynamiki społecznej nigdy nie jest za dużo (co nawiasem mówiąc kłóci się z założeniami koncepcji Comte’a). Akceptujemy myślenie, zgodnie z którym winniśmy ślepo ufać wszelkim przejawom ruchu/poruszenia społecznego i zgodnie z którym wysokie wskaźniki ilościowe aktywności/partycypacji społecznej zawsze powinny nas - jako socjologów - cieszyć, a nigdy martwić.

\section{PRZPADEK TRZECI: RE-ANIMATORZY MIASTA}

Widać od pewnego czasu, że ruchy miejskie coraz bardziej upodabniają się do partii politycznych ${ }^{5}$. Dlatego ich nastawienie do działań animacyjnych i do stałego poszerzania - choćby i trochę na siłę - zakresu partycypacji społecznej nie jest już tak entuzjastyczne jak jeszcze przed kilkoma laty. Oczywiście aktywizowanie mieszkańców i wysiłki mające na celu uwalnianie energii obywatelskiej ani na moment nie przestały być najważniejszymi hasłami działaczy identyfikujących się z ruchami miejskimi. Jednocześnie jednak to uruchamianie społeczności miejskiej zaczęło być przez nich pojmowane coraz bardziej metaforycznie i umownie: np. jako mobilizowanie do udziału w krótkotrwałych akcjach/imprezach majacych jedynie znaczenie symboliczne lub jako pozyskiwanie deklaracji sympatii, na co dzień mającej objawiać się nie tyle jakimiś konkretnymi działaniami, ile wręcz przeciwnie - życzliwy m nieza angażow aniem, przyjazną biernościa, dzięki której określone rozwiązania mające uczynić miasto bardziej przyjaznym będa, paradoksalnie, łatwiejsze do wprowadzenia.

Swoistej pragmatyzacji ruchów miejskich coraz częściej uznających, że do osiagnięcia ich najważniejszych celów programowych wcale nie jest im potrzebne żadne ożywienie społeczne, a tylko pasywne poparcie mieszkańców, towarzyszy rozkwit najróżniejszych nowych inicjatyw oddolnych, które w przeciwieństwie do ruchów miejskich są w dalszym ciagu przekonane, że ciagłe nasycanie przestrzeni miejskiej coraz to nowymi formami aktywności jest najlepszą drogą prowadzącą do reaktywowania ducha miejskości i do odzyskania miasta dla mieszkańców ${ }^{6}$. Modne stają się więc rozmaite miejskie performance'y artystyczne i społeczno-kulturalne, które oparte są na formule DIWO (Do It With Others) lub DITO (Do It Together)7. Rośnie popularność

\footnotetext{
${ }_{5}^{5}$ Zob. P. Pluciński, Im lepiej, tym gorzej albo widmo kryzysu miejskich ruchów społecznych? w niniejszym zeszycie (s. 409-423).

${ }^{6}$ Por. np. Ł. Bukowiecki, M. Obarska, X. Stańczyk, Miasto na żqdanie. Aktywizm, polityki miejskie, doświadczenia, Wyd. UW, Warszawa 2014.

7 Więcej o podobnych inicjatywach - zob. np. A. Nacher (red.), Spacerowicze, nomadzi i sieciowi łowcy okazji, Małopolski Instytut Kultury, Kraków 2013.
} 
takich zjawisk, jak urbex (urban exploring) ${ }^{8}$, nielegalne nasadzenia w mieście (guerrilla gardening) ${ }^{9}$ czy tzw. estetyczna partyzantka ${ }^{10}$.

Paradoksalnie jednak, tak właśnie - jako na miejskie aktywności, które mają (choćby na krótko) przywrócić władzę nad przestrzenią miasta mieszkańcom i które mają być więziotwórcze - interpretować wolno tak różne formy aktywności, jak z jednej strony wspomniane przed chwila paraartystyczne gry w przestrzeni miejskiej (i z przestrzenią miejska), a z drugiej - np. przemarsze kibiców przez miasto. Zarówno bowiem osławieni hipsterzy (post- bądź altermaterialiści?) sadzący pod osłoną nocy drzewka na nieużytkach miejskich lub oplatajacy kolorową włóczka kanciaste oparcia parkowych ławek, jak i maszerujacy ulicami miasta kibice komunikuja wszem i wobec, że ich miejskie działania/akcje maja znaczenie miastotwórcze. Po wtóre, wszyscy oni wydaja się wierzyć, że działają nie tylko w swoim imieniu, lecz również $\mathrm{w}$ imieniu biernych i niezaangażowanych mieszkańców. Po trzecie, łączy ich przekonanie, że ich działania nieuchronnie prowadza do rychłego wywołania lawiny konstruktywnych protestów antyestablishmentowych ${ }^{11}$.

Jednocześnie jednak nowi aktywiści miejscy budzą już mieszane uczucia i - coraz częściej - staja się przedmiotem tyleż ostrej, co ironicznej krytyki. Uważni obserwatorzy ich poczynań zarzucają im np., że więcej jest w tych poczynaniach ukrytych funkcji marketingowych niż szczerego ducha miejskiego akcjonizmu ${ }^{12}$. Wiele podejmowanych przez nowych aktywistów miejskich działań klasyfikowanych jest jako przykłady deindywiduacji, w której bardziej chodzi o epizodyczne, ale za to intensywne przeżywanie wspólnotowości niż o wywieranie na rządzących długoterminowej presji mającej wymusić konkretne zmiany w polityce miejskiej ${ }^{13}$. Wreszcie, istot-

${ }^{8}$ Urban exploring lub urban exploration (często skracane do urbex) to rodzaj ekstremalnej turystyki miejskiej, która polega na eksplorowaniu i dokumentowaniu (fotograficznym, filmowym) skrajnie trudno dostępnych miejsc: np. podziemnych kanałów wodno-kanalizacyjnych, zamkniętych tuneli metra, szybów wentylacyjnych, dachów wysokościowców, budynków pofabrycznych, poszpitalnych, powojskowych itp.

${ }^{9}$ Guerrilla gardening to nielegalne i niezgodne z miejskimi planami zagospodarowania przestrzennego „akcje nasadzeniowe” mające na celu, z jednej strony, podnoszenie atrakcyjności miasta i jakości życia w mieście przez zwiększenie powierzchni miejskich terenów zielonych i generalnie przez zazielenianie miasta na wszelkie możliwe sposoby, z drugiej zaś - służące również kwestionowaniu i ograniczaniu (wszech)władzy biurokracji miejskiej w zakresie planowania i projektowania przestrzennego. Więcej na temat guerrilla gardening zob. np. http://www.guerrillagardening.org (dostęp: 12.01.2015).

${ }^{10}$ Więcej na temat tego pojęcia i przykładowych działań wpisujących się w ramy „estetycznej partyzantki” zob. np. w portalu „Design Attack”, https://designattack2011.wordpress. com/2011/01/03/miejska-partyzantka-estetyczna/ (dostęp: 12.01.2015).

${ }^{11}$ Za uderzająco trafną uznać by więc należało nazwę „Masa Krytyczna”, którą obrał dla siebie działajacy od 1992 r. (początkowo tylko w USA, dziś w kilkudziesięciu krajach) nieformalny ruch społeczny organizujacy przejazdy jak najliczniejszych grup rowerzystów przez centra wielkich miast. Przejazdom od lat towarzyszy to samo hasło: „My nie blokujemy ruchu, my jesteśmy ruchem”, mające na celu zwrócenie uwagi władz miejskich i mieszkańców na problemy i prawa rowerzystów.

${ }^{12}$ Wydaje się, że dobrym przykładem szybkiej komercjalizacji i instrumentalizacji jest historia flash mob'ów, które błyskawicznie zostały dostrzeżone i zawłaszczone przez marketingowców.

${ }_{13}$ Por. M. Krajewski (red.), Deindywiduacja. Socjologia zachowań zbiorowych, Wyd. Fundacji Bęc Zmiana, Warszawa 2014. 
ną cechą działań nowych aktywistów miejskich wydaje się dążenie do tego, aby łączyły one funkcje polityczno-propagandowo-mobilizacyjna z funkcja zabawowo-rozrywkowa. Inaczej mówiąc, podejmowane w przestrzeni miejskiej akcje mają służyć czemuś pożytecznemu, mają być uzasadnione jakimiś wyższymi racjami, ale mają też - dzięki wpisanej w nie ludyczności sprawiać przyjemność ${ }^{14}$. Co gorsza, to drugie zaczyna być ważniejsze niż to pierwsze.

\section{PRZYPADEK CZWARTY: SLOW MOTION}

Jeśli rośnie liczba podmiotów, dla których ruch i działanie stanowią wartość samą w sobie, i jeśli (motywowane korzyściami politycznymi, obywatelskimi, rynkowymi, estetyczno-artystycznymi) nawoływania do aktywizacji i upartycypacyjnienia życia miejskiego stają się tak częste, że hasła te zaczynają brzmieć trywialnie, można spodziewać się, że prędzej czy później wahadło zacznie się wychylać w drugą stronę. I rzeczywiście, lista gestów i inicjatyw, których wspólnym rysem jest chęć przeciwstawienia się wielu (nieakceptowanym i uznawanym za zbędne) przejawom „miejskiego akcjonizmu” jest już zaskakująco długa.

Otwieraja ja rozmaite mniej bądź bardziej populistyczne przeciw-ruchy miejskie, które sprzeciwiają się (ograniczając się jednak zazwyczaj do ironicznych akcji medialnych) różnym nowym modom miejskim, różnym nowym elementom miejskiego lifestyle'u postrzeganym jako pretensjonalne i próżne. Dobrym przykładem takiego przeciw-ruchu może być zainicjowana niedawno przez Dominika Zdorta na łamach „Rzeczpospolitej” krucjata przeciwko miejskim biegom ulicznym. Ukuty przez Zdorta (skądinąd zręcznie i z dużym wyczuciem językowym) termin „biegactwo” ma przeciwstawiać miejskich „normalsów” (np. kierowców przemieszczających się przez miasto własnymi samochodami) miejskim fantastom, którzy jakoby nie rozumieja, czym jest miasto i jaka jest jego natura. Inny przykład praktyk, które są nakierowane raczej na powstrzymywanie niż na aktywizowanie i pobudzanie, to coraz popularniejsze oddolne, par excellence obywatelskie akcje wymierzone przeciwko nielegalnym (lub nawet legalnym, ale zbyt inwazyjnym) reklamom szpecącym przestrzeń miejską ${ }^{15}$. Zwalnianie, powstrzymywanie się i orientowanie się na kulturę umiaru w czasach nadmiaru ${ }^{16}$ to również najkrótsza charakterystyka takich modnych dziś (i głównie miej-

\footnotetext{
${ }^{14}$ Zob. M. Frąckowiak, Opór sympatyczny, w: E. Jabłońska (red.), Nieużytki sztuki, Galeria BWA, Zielona Góra 2014.

${ }^{15}$ Więcej na ten temat - zob. na stronie internetowej stowarzyszenia „Miasto Moje a w Nim”: http://miastomoje.org (dostęp: 3.02.2015).

${ }_{16}$ Zob. „Kultura Współczesna” 2013, nr 1, zredagowana jako numer tematyczny poświęcony w całości „kulturze nadmiaru w czasach niedomiaru”.
} 
skich, a właściwie wielkomiejskich) trendów jak slow movement (slow food, slow fashion, slow media, slow parenting, slow technology, slow travel itd.), antykonsumpcjonistyczny minimalizm ${ }^{17}$ czy work-life balance ${ }^{18}$.

\section{ZAKOŃCZENIE}

Nieufność wobec polityki aktywizujących impulsów ${ }^{19}$ i wobec, szerzej mówiąc, pewnej ogólniejszej zasady rządzenia polegającej na aktywizowaniu i włączaniu do gry uśpionych dotąd bądź celowo marginalizowanych potencjałów społecznych może się wydać - sama w sobie - czymśs z gruntu niesłusznym i niemal niedorzecznym. Oczywiście - wszyscy zdajemy sobie sprawę, że działania (zarówno te oddolne, jak i te projektowane przez instytucje par excellence polityczne) moga przybierać (i często przybieraja) wysoce niepożądane formy oraz że mogą one prowadzić (i często prowadza) do niepożądanych rezultatów. Wszyscy zdajemy sobie też sprawę z tego, że wiele form aktywności podejmowanych przez jednostki uznające się za w pełni autonomicznych aktorów społecznych to takie jej formy, w które zostały one w jakiśs sposób wplątane (historie tych „wplątań” bardzo dobrze tłumaczy choćby stara, marksowska koncepcja fałszywej świadomości, będąca zreszta po dziś dzień jedna z ważniejszych inspiracji zarówno dla niemarksowskiej socjologii wiedzy, jak i dla niemarksowskiej socjologii władzy). Nie będzie również żadnym odkryciem stwierdzenie, że bardzo dużo działań sygnowanych przez rozmaite podmioty władzy (centralnej - lokalnej, rządowej - samorządowej) to tylko działania pozorne lub zastępcze - pewnego rodzaju inscenizacje, których najważniejszym celem jest odwracanie uwagi.

Jednocześnie kiedy podjęte działania nie spełniaja pokładanych w nich nadziei, traktuje się to najczęściej jako wypadki przy pracy, jako mało znaczące wyłomy $\mathrm{w}$ dobrze na co dzień funkcjonującym porządku opartym na idei demokratyzowania przez działanie oraz na idei poprawianial naprawiania przez uczestnictwo. W rezultacie socjologiczna refleksja nad źle działającymi działaniami jest wciąż uderzająco schematyczna. Można odnieść wrażenie, że cały czas opisujemy jedno i to samo (funkcje ukryte i skutki uboczne działań, działania maskujące, konflikty interesów w rodzaju słynnego syndromu NIMBY - Not In My Back Yard itp.). Dopiero stosunkowo niedawno ten spodziewany schemat zaczęły uzupełniać analizy funkcjonowania systemów złożonych (również systemów-miast ${ }^{20}$ ), kładące szczególny nacisk na ich emergentność. Inna, stosunkowo

${ }_{17}$ Zob. M. Skowrońska, Minimalizm i chomikowanie; jak radzić sobie z nadmiarem przedmiotów?, „Kultura Współczesna” 2013, nr 1, s. 89-104.

${ }_{18}$ Zob. np. C. Sadowska-Snarska (red.), Praca-życie. Studium porównawcze Finlandia-Polska-Hiszpania, Wyd. WSE w Białymstoku, Białystok 2007.

${ }_{19}$ Zob. M. Krajewski, M. Frąckowiak, Polityka impulsów i rzeczy, w: B. Świątkowska (red.), My $i$ Oni. Przestrzenie wspólne i projektowanie dla wspólnoty, Wyd. Fundacji Bęc Zmiana, Warszawa 2015.

${ }^{20}$ Więcej na temat miasta-systemu i badań postrzegających miasto jako system - zob. np. J. J. Parysek, Miasto w ujęciu systemowym w niniejszym zeszycie (s. 27-53). 
nowa i bardzo, moim zdaniem, pozytywna cecha studiów miejskich to coraz częstsze przyjmowanie przez badaczy Latourowskiego spojrzenia na miasto. W ujęciu Brunona Latoura sprawczość przysługuje nie tylko aktorom ludzkim, ale i aktorom-nie-ludzkim (zwierzętom, technologiom, architekturze i rozwiązaniom przestrzennym, infrastrukturze miejskiej, siłom natury itp.). Miasto jest więc systemem hybrydalnym, jest siecia, która splata w jedna całość skrajnie różne kategorie podmiotów, różniących się między sobą nie tylko takimi cechami, jak stopień intencjonalności czy urefleksyjnienia podejmowanej aktywności, lecz także status ontologiczny ${ }^{21}$.

Kłopot w tym, że to wciąż za mało. Brakuje np. badań na temat (sygnalizowanej już w tym artykule) kwestii górnego poziomu partycypacji s połecznej, po przekroczeniu którego koszty procesów decyzyjnych stają się absurdalnie wysokie, a system miejski - praktycznie niesterowalny. Paradoksalnie, ogólnych modeli teoretycznych, które zajmują się tym zagadnieniem, jest stosunkowo dużo. Dostarcza ich choćby wciąż dynamicznie rozwijająca się teoria wyboru publicznego. Niezwykle trudno jednak znaleźć badania, które zajmują się dylematami i pułapkami związanymi z horyzontalną i zwłaszcza wertykalna partycypacją in concreto (te zaś, które to czynia, nie prowadzą niestety do konkluzyjnych i oryginalnych wniosków ${ }^{22}$ ). Być może przyczyną tego stanu rzeczy jest po prostu obawa, że już samo zainteresowanie kosztami partycypacji oraz związanymi z nią niebezpieczeństwami może zostać odebrane jako atak na święte prawo podmiotowości i kwestionowanie potrzeby dalszego rozwijania demokracji społecznej.

Brakuje też w moim przekonaniu badań, które próbowałyby spoglądać na praktyki miejskie z perspektywy socjologii emocji. Wiele (wydaje się, że coraz więcej - również była już o tym mowa w niniejszym artykule) form i sposobów angażowania się w życie miejskie podporządkowanych jest bowiem głównie, niekiedy wyłącznie, zyskom emocjonalnym ${ }^{23}$. Pytanie, w jakim stopniu i w jakim znaczeniu wykorzystywanie miasta, miejskości, a nawet polityk miejskich w celu kolekcjonowania indywidualnych i zbiorowych doświadczeń emocjonalnych zmienia samo miasto oraz owe polityki.

Brakuje, po trzecie, badań, które patrzyłyby na stare i nowe ruchy miejskie nie tylko z perspektywy politologicznej (widzącej w nich nowych, potencjalnie ciekawych graczy na miejskiej scenie politycznej) i nie tylko z perspektywy socjologiczno-kulturoznawczej (szukajacej w nich przede wszystkim świadectw społeczno-kulturowego oporu przeciwko zastanemu establishmentowi), lecz także z perspektywy socjologii organizacji/ teorii za-

${ }^{21}$ Zob. Zob. B. Latour, Splatajac na nowo to, co spoteczne. Wprowadzenie do teorii aktora-sieci, Universitas, Kraków 2010, na temat wykorzystania Latourowskiej perspektywy w badaniach socjologicznych zob. też A. Nowak, Ontologia czy polityka wiedzy? Wyobraźnia socjologiczna a społeczne studia nad nauka, „Studia Metodologiczne” 31, 2013.

22 Zob. np. A. Peisert, P. Matczak, Aktywność lokalnej wspólnoty politycznej a modele partycypacji, w: A. Olech (red.), Dyktat czy uczestnictwo? Diagnoza partycypacji publicznej w Polsce, t. 1 , Fundacja Instytut Spraw Publicznych, Warszawa 2012.

${ }_{23}$ Por. A. Hochschild, Zarzadzanie emocjami. Komercjalizacja ludzkich uczuć, WN PWN, Warszawa 2009. 
rządzania. Uzupełnienie dwóch pierwszych o tę perspektywę organizacyjna pomogłoby lepiej zdać sobie sprawę ze wszystkich prawno-instytucjonalnych i finansowych ograniczeń oraz barier, jakie napotykać moga zgłaszane przez ruchy miejskie pomysły na lepsze miasto. Mam świadomość, że postulat poddawania projektów i programów sygnowanych przez ruchy miejskie swoistemu studium prawno-finansowej wykonalności może być odebrany jako próba tłamszenia entuzjazmu działaczy miejskich i jako forsowanie gorzkiego realizmu, który uziemia wszystkie odważniejsze wizje miejskie. Z drugiej strony, osadzenie myślenia o sposobach udoskonalania miasta w jednoznacznie nazwanych i jasno wskazanych ramach organizacyjno-instytucjonalnych chroni je przed utopizmem.

Brakuje, po czwarte, badań, których celem byłoby rozpoznawanie uwarunkowań i przyczyn miejskiego bezruchu i marazmu. Wiele z tych uwarunkowań i przyczyn wydaje się, że zostało już dobrze opisanych ${ }^{24}$. Nadal mało jednak wiemy o rzeczywistej skali i o metodach polityki/polityk powstrzymywania w znaczeniu, w jakim pisze o tym zjawisku Jacques Rancière ${ }^{25}$; nadal nie umiemy powiedzieć zbyt wiele np. na temat wykluczajacych z uczestnictwa $\mathrm{w}$ życiu miasta estetyk i rozwiązań przestrzennych ${ }^{26}$.

Brakuje wreszcie - jakkolwiek przewrotnie by to zabrzmiało - socjologicznej refleksji na temat miasto- i ładotwórczych konsekwencji zarówno Rancière'owskiego (aktywnego i opierającego się zazwyczaj na jakiejś władzy instytucjonalnej) powstrzymywania, jak i (dobrowolnego) bezruchu społecznego ${ }^{27}$. Być może wcale nie ma podstaw, by mówić o jakichkolwiek stabilizujących funkcjach społecznego/obywatelskiego niezaangażowania. Jeśliby tak było, hipotezę otwierająca i poniekąd programujacą cały niniejszy artykuł, należałoby odrzucić i szybko o niej zapomnieć. Jeśli jednak jej odrzucenie nie

${ }_{24}$ Zob. np. R. Putnam, Samotna gra w kręgle. Upadek i odrodzenie wspólnot lokalnych w Stanach Zjednoczonych, Wydawnictwa Akademickie i Profesjonalne, Warszawa 2009, zob. również R. Sennett, Upadek człowieka publicznego, Muza, Warszawa 2009.

${ }_{25}$ Zob. J. Rancière, Dzielenie postrzegalnego. Estetyka i polityka, Wydawnictwo Korporacja Ha!art, Kraków 2008.

${ }^{26}$ Niedawno prasę obiegły wykonane we francuskim mieście Angoulême zdjęcia pokazujace szczelnie okratowane ławki. Okratowanie miało je zabezpieczać przed bezdomnymi, którzy kładli się na nich i spali. W mediach, zwłaszcza oczywiście w Internecie, bez trudu można znaleźć dziesiątki podobnych doniesień. W rzeczywiście jednak wciąż brakuje nam twardych, systematycznych i osadzonych w konkrecie analiz praktyk estetycznych (i praktyk organizacyjnych), które skutkuja wykluczaniem oraz wypychaniem z miejskiej przestrzeni publicznej. Jedna z niewielu znanych mi udanych prób realizacji konsekwentnego, spójnego metodologicznie badania socjologicznego, którego celem była identyfikacja i swoiste skatalogowanie cech „estetyki wypychającej”, jest nieopublikowana rozprawa doktorska Michała Podgórskiego zatytułowana Ucieczka od wizualności i jej społeczne konsekwencje. Fenomen estetyki haptycznej (Instytut Socjologii UAM, Poznań 2001).

${ }^{27}$ Nie jest oczywiście tak, że ten obywatelski bezruch nie interesował i nie interesuje socjologów. Dobrym przykładem żywego zainteresowania bezruchem społecznym może być zredagowana przez M. Nowaka i M. Nowosielskiego książka pt. Czy spoteczny bezruch? O społeczeństwie obywatelskim i aktywności we wspótczesnej Polsce (Instytut Zachodni, Poznań 2006). Zarówno jednak ta, jak i wiele podobnych publikacji niejako z góry traktują bezruch jako zjawisko negatywne, dezintegrujace; pytanie o jego inne, mniej spodziewane, mniej samonarzucające się konsekwencje i funkcje właściwie w nich nie pada. 
okazałoby się tak łatwe, jak może się to zdawać na pierwszy rzut oka, byłoby to równoznaczne z koniecznością istotnego zrewidowania naszych wyobrażeń o społecznym konstruowaniu miasta.

$$
* * *
$$

Nie tak dawno temu Mirosława Marody zauważyła, że współczesne społeczeństwo nie potrzebuje już zaangażowanych obywateli, lecz kompetentnych użytkowników instytucji systemowych ${ }^{28}$. Dokładnie to samo powiedzieć można o społeczeństwie miejskim (które notabene staje się na naszych oczach synonimem społeczeństwa po prostu). Co to jednak oznacza w praktyce? To przede wszystkim, że gros wysiłków i aktywności owego nowego społeczeństwa miejskiego koncentruje się (a mówiąc ostrożniej: będzie się koncentrować w niedalekiej już przyszłości) wokół następujących dwóch celów. Po pierwsze, wokół zastępowania względnie swobodnych, autonomicznych sposobów bycia w mieści e czymśs, co można by określić mianem programów uży wa nia mi a sta, niebędących niczym innym, jak instrukcjami obsługi dozwolonego, dopuszczalnego, „właściwego” posługiwania się miaste m². Te programy czy też instrukcje używania miasta rozumieć można jako sposoby mediowania między określonymi indywidualnymi i mikrozbiorowymi interesami a takimi bądź innymi id eologia mi miasta oraz takimi bądź innymi mi tami dobrze urzadzonego i dobrze funkcjonującego miasta. Można je też pojmować jako synonimy miejskiej normalności i jako jej odbicia. Czy jeszcze inaczej: z punktu widzenia znakomitej większości jednostek żyjących w mieście (doświadczajacych na rozmaite sposoby miasta) układają się one w system instrukcji wdrażających w miejską normalność i pomagających funkcjonować w mieście we względnie bezkolizyjny sposób. Drugim głównym zadaniem dla miejskich społeczności byłoby oczywiście w tej prognozie mniej lub bardziej skrupulatne uczenie się „instrukcji miejskich”.

W konsekwencji byłoby to jednak równoznaczne ze stopniowym standaryzowaniem miasta i miejskości i ze stałym poszerzaniem władzy owego Rancière'owskiego „dzielenia postrzegalnego” będącego - każdorazowo - wybitnie restrykcyjna, wybitnie dyscyplinująca definicją określająca to, co m a prawo się w mieście zdarzać (i zarazem co jest w mieście nie do pomyślenia i nie do wyobrażenia). Tym samym sama idea miasta stawałaby się coraz bardziej „policyjna” i technokratyczna oraz coraz mniej liberalna - ze wszystkimi tego trudnymi dziś do przewidzenia i nawet do wyobrażenia sobie skutkami.

prof. dr hab. Rafat Drozdowski

Uniwersytet im. Adama Mickiewicza w Poznaniu

rafdrozd@amu.edu.pl

${ }_{28}$ Zob. M. Marody, O społecznym zakorzenieniu kultury uniwersytetu, w: P. Sztompka, K. Matuszek (red.), Idea uniwersytetu. Reaktywacja, Wyd. UJ, Kraków 2014.

${ }_{29}$ Por. R. Drozdowski, Programy (używania) miasta, „Przegląd Humanistyczny” 2010, nr 3. 


\section{TOWARDS A CITY-FORMING STILLNESS?}

\section{Summary}

This paper is an attempt to analyse some 'town-forming' functions of selected forms and manifestations of city activity, citizens' participation and participatory democracy. A hypothesis is also deliberated, according to which certain consequences may result from certain non-performance policies and hindering strategies, both in the meaning proposed by J. Rancière as well in a more common, or everyday sense, which is usually linked to social stagnation, fatigue and stillness. 